özet

Temel kișisi Karagöz ile aynı adı tașıyan gölge oyunumuz Karagöz'de ele alınmamıș karakter denenmemiș eylem yoktur dense abartıı olmaz. Karagöz "fasıllarının" konuları ve kahramanları Osmanlı toplumunun ilginç yansımalarıdır. Tanzimat döneminden bașlayarak Karagöz oyunlarının “yazma” niteliğinin bozulduğunu, "sözlü” geleneğin "yazı”yla değiștiğini, yeni yazımlarının, basım ve yayımının gerçekleștiğini görüyoruz. Geleneksel çizgideki oyunların yazılı versiyonlarının ve yeniden yazımlarının yanı sıra, özellikle II. Meșrutiyet sürecinde "nev-icâd" oyunların hızla yazıldığını, Karagöz'ün, yeni bir siyasal / toplumsal yapıda, değișen toplumun hemen bütün sorunlarını, öğretici (didaktik) kimliğiyle irdeleyen bir kahraman olarak karșımıza çıktığını görürüz Doktor olmuștur, gezgin olmuștur... vb. . Üsküdar'da bașlayan gezisi, Kağıthâne serüvenlerinden Londra'ya uzanır... Bana kalırsa, Karagöz oyunlarının, II. Meșrutiyet döneminde bu denli ilgi görüp birden bire çoğalmasının, en belirleyici nedeni, 10 Ağustos 1908'de, yayımlanan Karagöz gazetesidir. 1908'den 1955 yılına değin 47 yılda, 4785 sayı yayımlanan Karagöz, bir gülmece gazetesi olarak basın tarihimizde, yayın yașamıyla hâlâ ilginçliğini koruyan, benzerini olușturmakta zorlandığımız bir yayın organıdır. Araștırmalarımda karșılașarak değerlendirdiğim Karagöz Evleniyor (1913) Karagöz dergisinin bir bugüne dek ele alınmamıș ve neredeyse unutulmuș bir sayısıdır. Yazarını bilmediğimiz bu kitap toplumun hakkınad konușmaya utandığı cinsel bilgileri evlilik sürecini anlatan bir oyunla anlatır. Evlilik hazırlıklarından cinsel hastalıklara değin neredeyse bütün bilgileri içeren bu Karagöz oyununun gölge oyunu oalrak sahnelenip sahnelenmediğini de bilmiyoruz. Yine de cinselliğin Karagöz oyunlarında kullanılı̆̆ını ve oyunun Türkiye "müstehçenlik tarihi"nde özel bir yeri olduğunu belirtirsek oyunun öneminin daha da vurgulanacağına inanıyorum.

Abstract
It wouldn't be an exaggeration to say that there is no character left and
no action untried by Karagöz, the protagonist of our shadow play of the
same name Karagöz. Subjects and characters of the karagöz episodes
are the interesting reflections of Ottoman society. We see that beginning
from the Tanzimat period, "writing" quality of Karagöz plays has been
degraded, "written" tradition took place of the "oral" tradition, new
writings, editions and publications are realized. Besides writings and
re-writings of the plays on the traditional line; we notice that, especially
in the period of II. Constitutional Monarchy, plays with new subjects

CINSEL BILGILERI ÖĞRENIRKEN SAĞDICIMIZ KARAGÖZ : KARAGÖZ EVLENIYOR (1913) OYUNU ${ }^{1}$

\author{
KARAGÖZ - \\ OUR BEST MAN \\ THROUGH SEXUAL \\ INFORMATION: THE \\ PLAY -KARAGÖZ \\ IS GETTING \\ MARRIED (1913)
}

\section{EfdAl SEVINÇLi*}

* Yrd.Doç.Dr., Yașar Üniversitesi, İletișim Fakültesi, Görsel İletișim Tasarımı

1 Karagöz Evleniyor, Karagöz Kütübhânesi, Aded: 2, Nâșiri: Karagöz Gazetesi, Her Hakkı Mahfûzdur, Der-saadet / İstanbul, Matbaa-i Nefâset - Vezir Hân, 1329./ Karagöz Evleniyor, bibliyografik bilgi olarak kaynakçalarda yok. Ayrıca hiçbir tanıtımının, değerlendirmesinin yapılmadığını da görüyoruz. Bkz: Tiyatro Bibliyografyası (1859-1928), Haz.: T. Poyraz - N. Tuğrul, Ankara, Milli Kütüphane Yayınları, 1967; Seyfettin Özege Bağıș Kitapları Katalogu, c.1-2, A-K, Haz: A.Bayram M.S.Çöğenli, Erzurum, Atatürk Üniversitesi Basımevi, Atatürk Üniversitesi Kütüphanesi Yayınları, 1978; M. Sabri Koz, “Karagöz Üzerine Seçme 


\section{EFDAL SEVINÇLI}

Kaynakça”, Yıktın Perdeyi Eyledin Vîrân, Istanbul, YKY, 2004, ss. 201-214. [Karagöz Kütüphanesi'nin ilk kitabı

Karagöz Matbahda (1913) ile Karagöz Evleniyor'dan ilk söz eden, Karagöz, Psiko-sosyal Bir Deneme (1941, s. 53) incelemesiyle S. Esat Siyavușgil'dir. Cevdet Kudret'in, Karagöz-I- (1968), Metin And'ın, Geleneksel Türk Tiyatrosu (1985) incelemelerinde adları geçmeyen kitapları, Prof. Dr. Saim Sakaoğlu, Türk Gölge Oyunu Karagöz (2003, s.91)'de, Siyavușgil'den aktararak adlarını veriyor. were written rapidly and that Karagöz came out as a protagonist who considered nearly all problems of the society of a political and social changing structure with his didactic character. For instance, Karagöz is a doctor, traveler...His travel beginning from Üsküdar, passes to London through the adventures of Kağıthane...In my opinion, the most significant reason that in the period of II. Constitutional Monarchy,such interest was shown to the Karagöz plays and that they were suddenly accumulated is the KARAGÖZ journal published in 10th August 1908. Karagöz, in which Karagöz and Hacivad are the protagonists, is a humorous journal that keeps the quality of being interesting with a press life including 4785 issue in 47 years from 1908 to 1955, and that we have difficulties to make a similar one. In my research, I evaluate the book Karagöz is Getting Married (1913) an issue of Karagöz journal which has never been analyzed so far and almost left at the background. We don't know the writer of this book in which sexual information that society is ashamed to talk about is told in relation with the marriage process in the form of a play. We also don't know if this Karagöz play with new subject telling about nearly all information from marriage preparations to sexual diseases was performed on a shadow or put on the scene or not. Nevertheless, I believe that if we say that sexuality is used within the Karagöz tradition and that it has a distinct part in the "history of obscenity" in Turkey, the importance of the work will be more emphasized.

Key Words: Karagöz, humorous, the play Karagöz is Getting Married, Sexual Information...

$$
\text { बैซือ }
$$




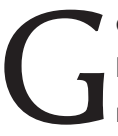
eleneksel tiyatromuzun bașkahramanı Karagözümüzün bilinen özelliklerini, Türk tiyatrosunun seçkin araștırmacılarını önünde anlatarak söze bașlamayı doğrusu uygun bulmasam da bildirimin içeriğini olușturan, nicedir, varlığı üstüne, sağlıklı, doyurucu bilgiler edinemediğim, kitaplığımdaki köșesinden bana, sürekli el eden, göz kırpan Karagöz Evleniyor'un önce adından, yazarından, yayıncısından, yayınevinden, basıldığı yıldan bașlayıp konusunu sizlerle paylaștıkça, Karagözümüzün temel özelliklerinden söz etmemi, kitabın kendisi isteyecek!.. Ancak Karagöz Evleniyor'u yaratan koșullara, değerlere, kısaca da olsa değinmeden, bu "kitabı" tanıtmaya geçmeyeceğim. Çünkü anımsamamız gereken kimi bilgilerin tam yerindeyiz...

Hepimiz biliyoruz, Karagöz'ün, neredeyse yapmadığı iș, girmediği kılık yoktur desem, gerçeği fazla abartmamıș olurum, Karagöz "fasıllarının" konuları ve kahramanları Osmanlı toplumunun ilginç yansımalarıdır. ${ }^{2}$ Tanzimat döneminden bașlayarak Karagöz oyunlarının "yazma" niteliğinin bozulduğunu, "sözlü" geleneğin "yazı"yla değiștiğini, yeni yazımlarının, basım ve yayımının gerçekleștiğini görüyoruz. Özellikle "kâr-ı kadîm" üzere oynanan oyunların yazıya aktarılıșının yanında "nev-icâd" oyunların da yazıldığını, bu oyunların kimilerinin, oynatılanlara metin olarak benzeseler de bir çoğunun neredeyse sadece adlarının dıșında hemen hiç bir benzerliğinin kalmadığını biliyoruz.

"Kâr-ı kadîm üzere" yazılan bu oyunların ${ }^{3}$ kimilerinin, Osmanlı Tiyatrosuyla bağlantısını, “ilk müslüman aktörümüz Ahmet Necip Efendi”nin yazdığı metinler görünüște sağlasa da bu dönem, irdeleyip değerlendirmemiz açısından karanlıklarla doludur.

Ancak bu karanlıklara karșın, Osmanlı gazetelerinin kimi bilgileri aydınlatmada, hâlâ ip uçları sakladığına inanıyorum. Çünkü gazete ile tiyatronun, Batılılașma, yenileșme sürecindeki ortak-

\section{${ }^{2}$ Metin And, Dünyada ve Bizde \\ Gölge Oyunu. (Ankara: T. İș Ban. Yay.,1977) , ss.239- 355. Metin And, Geleneksel Türk Tiyatrosu, Köylü ve Halk Tiyatrosu Gelenekleri. (İstanbul: İnkılâp Kitabevi Yay., 1985), ss. 271 - 336. Cevdet Kudret, Karagöz-I- (Ankara: Bilgi Yayınevi,1968), ss. 7 - 60. Sabri Esat Siyavușgil, Karagöz, Psiko-sosyal Bir Deneme (Maarif Vekaleti, 1941), ss. 90 -188 . \\ ${ }^{3}$ Prof.Dr.Saim Sakaoğlu, Türk} Gölge Oyunu Karagöz, Ankara, Akçağ Yay., 2003, ss.79 - 98. 
lıklarında, gelenekselin güncele aktarılması / uyarlanması isteğinde, Batıcı tiyatronun bir oyuncusunun, A.Necip Efendi'nin, Yazıcı oyununu, Karagöz'ün Aktör Olması yahut Komikliği, Ters Evlenme'yi, Sahte Gelin diye adlandırması, bize perdeden sahneye uzanan anlambilimsel bir sürecin sözcüklerini de öğretiyor: Karagöz'ün Aktör Olması yahut Komikliği ve Sahte Gelin. ${ }^{4}$

"Kâr-ı kadîm üzere" yazılan oyunların yazıya aktarımı ve yeniden yazılıșları yanında, özellikle II. Meșrutiyet sürecinde "nevicâd” oyunların hızla yazıldığını, Karagöz'ün, yeni bir siyasal / toplumsal yapıda, değișen toplumun hemen bütün sorunlarını, öğretici (didaktik) kimliğiyle irdeleyen bir kahraman olarak karșımıza çıktığını görürüz. Örneğin Karagöz doktordur, Üsküdar'da bașlayan gezisi, Kağıthâne serüvenlerinden Londra'ya uzanır... Karagöz'ü, gezmelerini Belgrad'da, İngiltere'de, İran'da, Mısır'da, Kafkasya'da, Balkanlarda sürdürürken buluruz.$^{5}$

Karagöz oyunlarının, II. Meșrutiyet döneminde bu denli ilgi görüp birden bire çoğalmasının, -bence- en belirleyici nedeni, Meșrutiyet'in duyurumundan 17 gün sonra, 10 Ağustos 1908'de, yayımlanan Karagöz gazetesidir. Karagöz, bir gülmece gazetesi olarak basın tarihimizde, yayın yașamıyla hâlâ ilginçliğini koruyan, benzerini olușturmakta zorlandığımız bir yayın organıdır. ${ }^{6}$ 1908'den 1955 yılına değin 47 yılda, 4785 sayı yayımlanan Karagöz'ün yaratıcısı, Türkiye'nin ilk karikatüristlerinden Ali Fuad Bey'dir ( ?- 1919) ${ }^{7}$. Haftada iki gün çıkan Karagöz, daha çok aydınlara seslenen, döneminin benzerleri Kalem ve Cem ${ }^{8}$ gibi gülmece dergilerinin, örneğin Fransızca özel bölümlerinin inatla sürdürüldüğü, seçkinci yayın anlayıșlarından, halka dönük yayıncılık anlayıșıyla hemen ayrılır. Gülmece tarihimizde, Teodor Kasab'ın emekleriyle Diyojen'den (1870), Hayâl'e (1873) uzanan çizgide, "Kanun dairesinde serbest olan" Karagöz ile Hacivad'ın birer kahraman olarak sahneden gazete sayfalarına aktarııșı, bir çizgi kahramanı olarak değerlendirilmesi, gelenekselden yararlanmanın yöntemi, yolu olarak ele alınıș, "bize özgü olanın bulunușu" yönünden, toplumsal tarihimizde, kültür tarihimizde çok önemli, bilinçli bir seçim ${ }^{9}$ olurken Karagöz gazetesi de Karagöz ile Hacivad'ı "bașkahraman" yapmıștır.
4 Metin And, Geleneksel Türk Tiyatrosu, Köylü ve Halk Tiyatrosu Gelenekleri, ss. 298 - 299. Cevdet Kudret, Karagöz-I, ss. 7 - 60. Prof. Dr. Saim Sakaoğlu, Türk Gölge Oyunu Karagöz, ss. 87 - 91. Sabri Esat Siyavușgil, Karagöz,Psikososyal bir deneme, s. 53.

5 Prof. Dr. Saim Sakaoğlu, .a.g.e., ss. 87 - 91.

6 Erol Üyepazarcı, "Uzun Soluklu Bir Halk Gazetesi Karagöz ve Kurucusu Ali Fuad Bey", Istanbul, Müteferrika, Sayı : 19, 2001, ss. 17 - 33. Erol Üyepazarcı, "Uzun Soluklu Halka Dönük Bir Mizah Gazetesi: Karagöz", Birgün Gazetesi, 23 Nisan 2008.

7 Turgut Çeviker, "ilk Türk Karikatürcüsü Ali Fuat Bey", Karikatür Üzerine Yazılar (İstanbul: İris Yay., 1997), ss.11 - 15. Ali Fuat Bey'in karikatürleri için bkz.: Turgut Çeviker, Osmanlı Tokadı (İstanbul: Adam Yay., 1986), ss. 9 - 11 .

8 Karikatür tarihimiz için bkz.: Turgut Çeviker, Gelișim Sürecinde Türk Karikatürü- I Tanzimat ve İstibdat Dönemi (1867-1878/1878-1908) ; c.-II- Meșrutiyet Dönemi (1908-1918) ; c.-III- Kurtuluș Savașı Dönemi (1918-1923) (Istanbul: Adam Yay.,1986, 1988, 1991). Tobias Heinzelmann, Osmanlı Karikatüründe Balkan Sorunu (1908-1914), Çev.: T. Noyan (İstanbul: Kitap Yayınevi, 2004), ss. 56 - 72.

9 Turgut Çeviker, "Karikatür ve Karagöz”, Karikatür Üzerine Yazılar (İstanbul: İris Yay., 1997), ss.1 -5. 
Gazetenin her sayısında, günün konusunu ișleyen bir Karagöz karikatürünün altında, "muhavere" bașlığıyla, Karagöz ile Hacivat'ın konușmalarını, halkın yabancı olmadığı bir dille, biçemle, gülmecenin en keskin oklarını tașıyarak yayımlanırken Teodor Kasab'ın Hayâl'inin ${ }^{10}$ kapağını süsleyen Karagöz ve Hacivat figürü, yıllar sonra, 1908'de, yurttașlarımızın karșılarına yeniden çıkarken ilginç bir bellek tazelenmesi yaratır. Basın dünyamızın güçlü sesi olan Karagöz, Karagöz ile Hacivad'ın diliyle, yine siyasal tașlamanın, toplumsal eleștirinin en önemli aracı olur. ${ }^{11} 31$ Mart günlerinde biraz yalpalasa (!) da Ali Fuad Bey'in yönetimindeki Karagöz, halkın ilgisini çektiğini, bir çok gazetenin tirajının / satıșının çok üstüne çıkarak gösterir...lilginçtir, 10 Ağustos 1908'den Ağustos 1914'e değin, kimi bașyazılar dıșında, Karagöz gazetesinde yayımlanan yazıların hepsi imzasızdır. Ancak Karagöz'ün, yazarlarının, çizerlerinin -kimilerinin ayrıntıı yașamöykülerini öğrenemesek de- hemen hepsini biliyoruz, tanıyoruz. Ali Fuat Bey'in kuruculuğundaki kadroda' ${ }^{12}$, Mahmud Nedim, Ali Haydar, Baha Tevfik, Burhan Cahit ${ }^{13}$ (Morkaya), Aka Gündüz bașyazarlık yaparlarken Ali Fuat Bey'in yanında Halit Naci ile Mehmet Baha'yı karikatürist olarak tanıyoruz. Elbette siyasal ve toplumsal yapının çalkantılı günlerinin, gülmeceye inanılmaz derecede "malzeme" vermesi yanında gazetede çalıșan yazarları ve karikatüristleri paylarının da Karagöz'ün tanıtımında etkili olduğunu unutmuyoruz...

\section{Karagöz Evleniyor "Nev-icâd" Bir Oyun mu ?}

Bu sorumun yanıtını, Karagöz Evleniyor'un içeriğini inceleyip kitabı tanıtırken birlikte bulmaya çalıșalım.Karagöz Evleniyor'un yazarını bilmiyoruz.Kapaktaki bilgileri anımsayalım: "Karagöz Evleniyor, Karagöz Kütübhânesi, Aded : 2, Nâșiri : Karagöz Gazetesi, Her Hakkı Mahfûzdur, Der-saadet / İstanbul, Matbaa-i Nefâset - Vezir Hân, 1329 (1913-E.S.)". Karagöz Evleniyor'un yazarı, kim/kimler olabilir?... "Kitabın Nâșiri : Karagöz Gazetesi" bilgisi dıșında bir bilgimiz yok...Kimi bașyazılar dıșında, Karagöz gazetesinde, 1908'den Ağustos 1914'e değin yayımlanan yazıların hepsinin imzasız olușunu unutmadan, 1913 yılında, "Haziran 1912'den Mayıs 1914'e kadar Karagöz'ün bașyazarlığını üstlenen Baha Tevfik Bey"in ${ }^{14}$ Ali Fuat Bey ile birlikte çalıștığını biliyoruz.
10 Turgut Çeviker, a.g.e. Tobias Heinzelmann, a.g.e., ss. 43-72.

11 Turgut Çeviker, “ Karikatür ve Karagöz”, Karikatür Üzerine Yazılar, ss.1-5.

12 Tobias Heinzelmann, Ön.ver.., ss. 52-56.

13 Burhan Cahid, Karagözün Fıkraları (İstanbul: Hacivad Matbaası,1926) Yașamöyküsü için bkz. "Burhan Cahit Morkaya (1892-1949)", Tanzimattan Bugüne Edebiyatçılar Ansiklopedisi, c. II (İstanbul: Yapı Kredi Yay., 2001), s. 570.

14 Tobias Heinzelmann, Ön.ver., s. 54. 
Gülmeceye yatkın kimliğiyle felsefeci yönünü, yayımladığı $\boldsymbol{P i -}$ yano, Düșünüyorum, Yirminci Asırda Zekâ, Felsefe, Çocuk Duygusu, Eșek, El-Ma'lûm gibi dergilerle gösteren Baha Tevfik, Karagöz Evleniyor'un yazarı olabilir mi? Bugün, bu öngörüyü doğrulama olanağımız yok! Ancak bu dönemde imzasız yazıların, ortaklașa üretildiğini düșünebiliriz... Çünkü, basın tarihimizde, imzasız yazıların yayımlandığı süreli yayınlarda, sansüre, her tür sorușturmaya karșı dayanıșma duygusuyla "ortak yazarlık" anlayıșının oluștuğunu Diyojen (1870)'den beri biliyoruz. ${ }^{15} \mathrm{Bu}$ bilgiyi, Karagöz Kütübhânesi bașlıklı dizide yayımlanan iki kitap için, Karagöz Matbahda ${ }^{16}$ (1913) ve Karagöz Evleniyor (1913) için de düșünebiliriz.

Karagöz Evleniyor'da, kahramanımız Karagöz, evliliğe hazırlanan bir Osmanlı gencidir. Kitabın adıyla olușan çağrıșımı, içindekilerle birleștirince, evliliğe hazırlanan bir Osmanlı gencine, Karagöz'e, evlilik için gerekli cinsel bilgilerin öğretildiği bir kitapla karșılașırız. İçerik, döneminde de bugün de ilgi çekmektedir. Karagöz Matbahda (1913), özünde bir yemek kitabıdır. Fakat Karagöz Evleniyor (1913), "șehveti teskin"den "tenâsül uzuvlarına”, sevișme tekniklerinden cinsel sağlığa değin, -dönemine göre- çok cesurca yazılmıș pornografik bilgilerini de kapsayan bölümleriyle -bence gözden kaçmıș-, Meșrutiyet yıllarının "Cinsel Bilgiler Ansiklopedisidir"! Ancak Kanlı Nigâr'dan Ters Evlenmeye, "phalllus"lu, "toraman"lı Karagözü yüzyıllardır tanıyan bizler için Karagöz Evleniyor'da anlatılanlar, salt bilginin sunumu, yöntemi açısından yeni olabilir...Açık saçıklığa da öğreticilik açısından bakabilen bir kültürün uzantısı olarak Karagöz Kütübhânesi'nin bu yayını, yeni yazılan oyun metinleriyle (diyaloglarıyla) ve düzyazı bilgilendirme bölümleriyle, Osmanlı gençlerine, Karagöz'ün diliyle seslenerek öğreticiliği (didaktizmi) amaçlamaktadır."Kâr-ı kadîm" üzere yazılan oyunlardan beri kahramanımız Karagözümüzün, "öğreticiliğini” koruyarak üç temel özelliğini, "güldürücülüğü”nü, "toplumsal / siyasal tașlamacılığı”nı ve "açık saçıkığı”nı bütün oyunlarında yansıttığını biliyoruz ${ }^{17}$. İște bu temel özellikleri kullanarak Meșrutiyet döneminde yazılan oyunların çokluğunu ${ }^{18}$ unutmadan, gözlerden uzak kalan "Nev-icâd" bir oyunu, Karagöz Evleniyor'un (1913) içiNDEKILER'ini okuyalım ve özetleyerek tanı-t-maya
15 Efdal Sevinçli, Namık Kemal ve Tiyatro (İzmir: D.E.Ü. G.S.F. Yay. , 1992) , s.92.

16 Karagöz Matbahda, Karagöz Kütübhânesi Aded : 1, Nâșiri: Karagöz Gazetesi, Her Hakkı

Mahfuzdur, Istanbul, Matbaa-i Nefâset - Vezir Hân, 1329 [1913], 79 s. Bkz..: Seyfettin Özege Bağıș Kitapları Katalogu, c.1-2, A-K, s. 368 ; M. Sabri Koz, "Karagöz Üzerine Seçme Kaynakça”, s. 205

17 Metin And, Dünyada ve Bizde Gölge Oyunu, ss. 327 - 355. Orhan Duru,

"Muhalif Oyun Karagöz",

Sanat Dünyamız, Sayı :

74, Kıș 1999, ss.153- 157. François Georgeon,"Osmanlı İmparatorluğu'ndaGülmek mi?", Doğuda Mizah, Hazırlayanlar : İ. Fenoglio - F. Georgeon, Çev.: Ali Berktay (İstanbul: YKY, 2000), ss.79101.

18Ali Sami Bey'in "Karagöz'ün Çapkınlıkları-Açık Hikâyeler" bașlığıyla yayımladığı,

Karagöz Baskında,

Karagöz Yatakda, Karagöz'ün Zifâf Odası, Karagöz Meyhanede, Karagöz Eğleniyor vb. kitapları yanında İhsan Rahîm Bey'in yayımladığı,10 cüz'den olușan Șarkılı

Kantolu Karagöz

Kitabı'ndaki oyunlar,

"Nevicâd" çalıșmaların ilginç örnekleridir. Bkz..: Cevdet Kudret, Karagöz-I, ss. 49 -60 ; Seyfettin Özege Bağıș Kitapları Katalogu ; M. Sabri Koz, "Karagöz Üzerine

Seçme Kaynakça" ; Prof. Dr. Saim Sakaoğlu, Türk Gölge Oyunu Karagöz. 
çalıșalım:

\section{Karagöz Evleniyor'un Bölümleri}

Mukaddime - [ss. 3-4 ] : "Karagöz Kütübhânesinin ikinci adedini teșkîl eden 'Karagöz Evleniyor' sırf alay etmek ve kar'ileri güldürmek için yazılmamıștır. Fakat bir fâide-i ictimâiyye dahi gözetilmemiștir. Karagöz Evleniyor, âdetâ bir nasîhat-nâmedir ki oğlunu veya kızını evlendirmek isteyen ebeveyne, evlenmek isteyen kimselere yol gösterir.Fakat Karagöz'ün tabiatı biraz komik olduğundan her ișe biraz gevezelik karıștırmadan duramaz..... Karagöz bunu sırf tabiatına mağlub olarak yapmıyor, hayır...Maksadı fâide husûlüdür...."

Davet-nâme - [s.5] : "Efendim, Karagöz kölelerinin velîme-i cem'iyyeti biraz sonra icrâ edileceğinden ișbu kitabı alan zât-ı âlilerinin dahi derûn-ı kitaba teșrif buyurmaları ricâ olunur. Gündüz davul çaldırılarak gece dahi Karagöz oyunu oynanacağı ma'rûzdur.Akraba ve evdâtın dahi ișbu düğüne teșrîf için teșvîk buyurulması ilâveten istirhâm olunur, ol bâbda... 22 Ağustos sene 1328 [ 4 Eylül 1912 - E. S. ] Bendeleri Karagöz.

\section{Birinci Bâb -[ss. 6-10 ] : Karagöz’ün Evlenmek İstemesi :}

Bu bölüm, karșılıklı konușma örgüsünde, Karagöz ile Hacivat'ın konușmalarıyla bașlar. Beșinci Bâb’ta, “Karagöz'ün İlk Kavgası"na değin içeriğiyle "fasıl" bölümünü olușturur. Görünüște, ne "giriș" (prolog) ne de "muhavere" bölümleri yoktur. Birebir örtüșmese de Mukaddime ile Davet-nâme, bu eksikliği gidermek için düșünülmüș bir sırayı anımsatırlar. Oyun, evliliği düșünen Karagöz'ün, Hacivat'ı aramasıyla bașlar : 


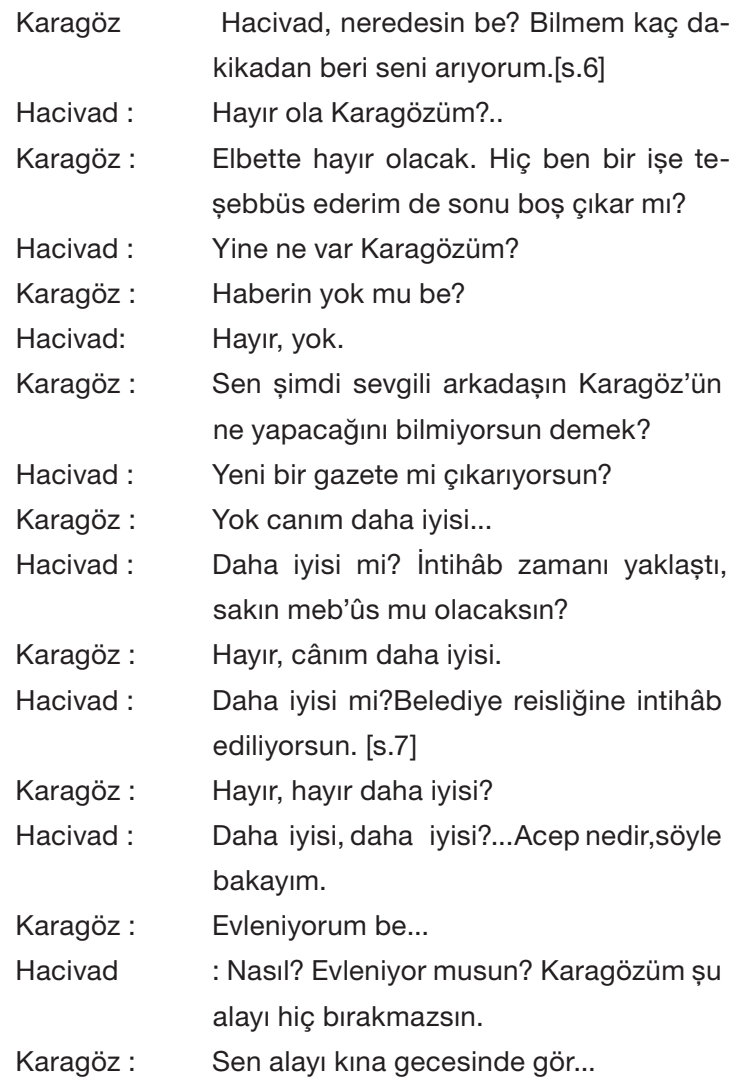

Hacivat'ın, dönemin kimi olaylarına, Meșrutiyet döneminde, basın dünyamızda birbiri ardına çıkarılan gazetelere, seçim günlerine vb. ilișkin göndermeler içeren tümceleriyle oyunda merak ögesi yükseltilirken konușma örgüsünde, 30 yașına giren Karagözümüz, evlilik için en iyi yașta olduğunu, artık geç kalmaması gerektiğini belirtir. Konu artık bellidir. Karagöz bir an önce evlenip "șehvetini teskin etmek" istemektedir! Ancak dolantı, evliliğin şakaya gelmediği, hayat arkadașlığının önemi, çocuk yapmak ve adam yetiștirmek gibi ciddi konuların tartıșımasıyla ve Hacivat'ın, "Bu iș mühim iștir. Acele ile olmaz. Șimdi gidelim. Biraz sonra uzun uzun düșünür, bir karar veririz." tümcesiyle ikin- 
CINSEL BILGILERi ÖĞRENIRKEN SAĞDICIMIZ KARAGÖZ

ci bölüme aktarılır.

İkinci Bâ b - [ss. 10-15 ] : Evlenmeden Evvel Düșünülecek Șeyler:

Hacivad: Gebakalım Karagöz,sen evleneceğim diyorsun ammâ, niçin evlenmeği istiyorsun, bunu söylemedin?

Karagöz: $\quad$ Cânım söyledim a. Insan bekârlıkta rahat edemiyor, kendine bakamıyor. Bakacak bir arkadaș lâzım. Ammâ sadık bir arkadaș. Bu da ancak insanın karısı olabilir...

Hacivad: Ne demek. Demek sen evlenirken ancak kendini düșünüyorsun, rahat edeyim diye evleniyorsun?

Karagöz: Öyle ya, dünyada yașamaktan maksad rahat etmek değil mi ?

Hacivad: Șimdi onları uzun uzun görüșeceğiz ammâ insan yalnız rahat etmek için mi evlenir?

Karagöz: $\quad$ Öyle ya, rahat etmek ve mes'ûd olmak için, neslini idâme için...

Hacivad: $\quad$ Pek doğru ammâ senin bilhassa bunun için evlendiğine inanamıyorum. Şimdiye kadar aklın nerede idi ...

Karagöz: Amerika'ya seyâhata gitmiști. Bu nasıl söz be? İnsanın aklı nerede olur?....

Karagöz'ün, "komiği" sağlamak için soruyu kendince yanıtlamasından sonra bir kadın görüp beğendiğini açıklayan, Hacivat'ın da "insan tanımadığı kadınla evlenir mi", "sonra geçinemezsin" tümceleriyle uzayan tartıșmaları, görünüște evlenmenin koșulIarının açıklanıșına bağlanır. Ancak söz, "șehvetin șiddeti"nden fazla birleșmenin zararlarına, Karagöz'ün doğacak erkek çocuğunun evlendirilmesine, parası için bir delikanlının ihtiyar kadınla, bir genç kızın da ihtiyar bir erkekle evlenmesinin sakıncalarına bağlanır ve yanlıș anlamalarla süslenerek sürer gider.

Üçüncü Bâb - [ss.16-25] Evlenmeden Evvel Düșünüle 
cek İctimâî Șeyler :

\begin{tabular}{|c|c|}
\hline Hacivad: & $\begin{array}{l}\text { Karagöz inanır mısın, senin evleneceğine } \\
\text { hâlâ inanamıyorum. }\end{array}$ \\
\hline Karagöz: & $\begin{array}{l}\text { Ben de inanmıyorum ammâ...kendi ken- } \\
\text { dine oluyor iște... }\end{array}$ \\
\hline Hacivad: & Karagöz gel șu lâtifeden vaz geçelim. \\
\hline Karagöz: & $\begin{array}{l}\text { Hacivad, lâtife değil dedik ya...Mutlaka } \\
\text { evleneceğim }\end{array}$ \\
\hline Hacivad: & $\begin{array}{l}\text { Peki ammâ evlenmeden evvel düșünüle- } \\
\text { cek șeyleri düșündün mü? }\end{array}$ \\
\hline Karagöz: & Yooo........ \\
\hline
\end{tabular}

Bu bölüm evlenilecek kadının kim olduğu, lâfının küfünün uyup uymadığı, görünüșe aldanılmaması gerektiği, kișiliği üstüne tanıyanlardan bilgi alınması, eğitim öğretim yakınlığı ile uyumsuzluğun yol açacağı sıkıntılar üstüne ilerleyen diyalogları içerir. Yanlıș yapılan evliliklerin kavgalarla kolayca yıkılacağını belirten Hacivat'a, "Peki ammâ ben karıdan bıkarsam" diye soran Karagöz'ün gülünç durumunu aktaran konușmalardan çıkan sonuç insan evleneceği kișiyi, annesini, babasını, ailesini iyi tanımalı, dedikodulara kulaklarını tıkayıp kuracağı ailede mutlu olacağına inanıyorsa evlenmeli öğüdüyle noktalanır.

\section{Dördüncü Bâb - [ss.25-33] Evlenmeden Evvel Yapılacak İșler :}

Bu bölüm, Karagöz'ün Hacivat'a iltifatlarıyla bașlar. Hacivat'ı, arkadașı ve büyüğü olușu nedeniyle "sağdıc"ı olarak görevlendiren Karagöz, Hacivat'ın bütün dediklerini yaptığını, gelin adayını uzun uzadıya araștırdığını, kendisine çok uygun bulduğunu, "istediğimden a'lâ, akıllı, dirâyetli, terbiyeli, ahlâklı, ma'lûmâtlı, Türkçesi tıbkı bana benziyor" diyerek tanımlar ve kendisinin "biraz daha akıllı” olduğunu belirtir. Evlenmeden önce yapılacak ișleri, Hacivat, Karagöz'e anlatmaya devam eder : Önce kıza, âdet üzere görücü gönderileceğini, görücüler beğenince de kızın Karagöz'e 


\section{CINSEL BiLGILERI ÖĞRENIRKEN SAĞDICIMIZ KARAGÖZ}

gösterileceğini söyleyince, güzellik, çirkinlik tartıșmaları, bizdeki evlenme âdetinin kötülüğü, uygar insanların akla değer verișleri ve kimin görücü olacağı, kılavuz kadınların ișlevleri, istenen ağırlık, yüz görümlüğü, nikâh ve hediyeler üstüne yapılan tartıșmalar, Karagöz'ün biraz "bozulan” Türkçesiyle anlatılır. Bu saçma âdetlerin kaldırımasını savunup çözümün de eğitim olduğuna birlikte karar verirlerken bölüm șu konușmayla noktalanır :

\begin{tabular}{|c|c|}
\hline Hacivad: & $\begin{array}{l}\text { İși gevezeliğe dökme canım...Sana dü- } \\
\text { ğünün nasıl olduğunu anlatayım.... }\end{array}$ \\
\hline Karagöz: & İyi ammâ, Hacivad, sen bunları nereden \\
\hline Hacivad: & $\begin{array}{l}\text { Allah göstermesin. Bu âdetler kalkma- } \\
\text { dan ben evlenmem. }\end{array}$ \\
\hline Karagöz: & Canım alayı bırak da anlat... \\
\hline Hacivad: & $\begin{array}{l}\text { Anlatacağım ammâ haydi vakit geçirme- } \\
\text { yelim hem gider, ba'zı ișlerimizi görürüz, } \\
\text { hem de anlatılacak șeyleri anlatıım, ol- } \\
\text { maz mı?.. }\end{array}$ \\
\hline Karagöz: & Olur, olur. \\
\hline
\end{tabular}

\section{Beșinci Bâb - [ss.33-41] Karagöz Zifâf Gecesinden Sonra :}

Bu bölümde, bir haftalık güvey olan Karagöz, Hacivat'la evlilik üstüne gevezelik yapar. Eșinin çok zarif, çok tatlı, evinin de mini mini bir saadet yuvası olduğunu vurgulayan Karagöz, kırkbeș yașına kadar bekar kalıșının tek suçlusunun da Hacivat olduğunu söyler. Hacivat da Karagöz'ün evliliğini sorgulayarak daha balayında olduklarını, Karagöz'ün Fizan'a ya da Nice'e gitmek isteyeceğini vurgulayıp onu kızdırmaya çalıșır. Kısa bir süre sonra birbirlerinin ahlakıyla, Sulukuleli olușlarıyla, adam olup olmamalarıyla alay edip kavgaya tutușurlar.Bölüm șu diyaloglarla biter :

Karagöz: Hacivad...Mahallemiz aynı...buradan çıkıp dört adım yürüyünce benim evimin kapısı ...Ya'ni...

Hacivad: Anladım....ben de Sulukuleliyim ammâ....

Karagöz: Mahallenin muhtarısın değil mi... 


\section{EFDAL SEVINÇLi}

Hacivad: Rey kazanmıș olsa idin sen red mi ederdin... Evet muhtarım ve iftihâr ederim...

Karagöz: Emin ol Hacivad...Çeribașı ihtiyâr...intihâb yakın...ister isen reyimi șimdi sana yazıp veririm...

Hacivad: Pis herif...benim ile alay edecek adam mı oldun...çık diyorum sana ...

Karagöz: Aman aman darıldın ise akșama yemek tablasını göndermeyiver...

Hacivad: Görürüz bakalım... Haydi git evine... Karı çarșafının eskiliğinden... terliğinin söküğünden bahs eder ise... buraya uğrama...

Karagöz : Uğramayıveririm...Aç kalmam ya...

Hacivad: Hay...hay...

Karagöz vedâ etmeden odadan hiddetle çıkar.

Karagöz Evleniyor'da, bu konușmadan Son Bahis [s.58] bölümüne değin konușma örgüsü, yerini -çoğunlukla- düzyazıya bırakır. Kitabın dili dikkatle incelenince, verilen bilgilerin, anlatıcının dilinden, Karagöz'ün dilinden aktarıldığı, zaman zaman da iç konușma düzeninde okuyucuya yansıtıldığı kolayca anlașılır. Yeni evlendiği karısıyla üç günde dokuz kez kavga ettiğini söyleyen Karagöz'ün Illk Kavgası ile Düșüncesi üstüne șu açıklamaları okuyoruz :

Karagöz'ün İlk Kavgası - [s.41] : Karagöz daha yatağından yeni kalkmıș, henüz keyfini çatamamıș, kahvesini, cigarasını, nargilesini içmemiș, enfiyesini çekmemiș, titiz bir halde somurtarak düșünüyor.

Karagöz'ün Düșüncesi - [s.41] : Anlașllan bu iște Hacivad'ın hakkı var, daha evleneli iki hafta olmadı, evin içinde kadın kedi, ben köpek.......Her gün kavga, her gün gürültü, bilmem bu gidișle halimiz ne olacak?..Üç günden beri dokuz kavga ettik.....Bilmem ilk kavgamız neden çıktı idi ? Hah, aklıma geldi...O gece yatakda gazete okumak istemiștim olmaz dedi.

Yataktan kanepeye, masaya, masadan da ayakta durarak gazete okumaya ulașan serüvenini anlatırken ağzını bozmada öl- 
çülü davrandığını savunan Karagöz, aralarındaki diyaloğu șöyle anlatır :

“...Bu sefer ne dese beğenirsiniz, öyle ayakta durarak hasta olacaksın. Hasta olursam ne olur, sanki bir doktor bulur kendimi tedavi ettiririm.

- $\quad$ Peki ammâ bu mahallede doktor yok, baytar var!..

- Demek siz hastalandıkça ona mürâcaat ediyorsunuz..

- $\quad$ Hadi hadi çal çene herif. Onun gibilerine siz mürâcaat edersiniz..."

Bu karșı çıkıșlara artık dayanamayıp "nezâketi elden bırakmayarak" karısını bir güzel dövdüğünü anlatan Karagöz, karısıyla kayınvalidesinin kavga edișlerini de görünce "hemen kavuğunu alıp" soluğu Hacivat'ın yanında alır.

\section{- Cinsel Bilgileri Öğrenmek}

Doğrusu, Karagöz Evleniyor'un en șașırtıcı bölümleri iște burada bașlıyor...Eğitim amaçlı da olsa yazılanlar, anlatılanlar, döneminin ahlak bilgisi değerleri açısından șașırtıcı. Daha önce de vurguladığım gibi "Karagöz Evleniyor (1913), "șehveti teskin”den "tenâsül uzuvlarına", sevișme tekniklerinden cinsel sağlığa değin, -dönemine göre- çok cesurca yazıımıș pornografik bilgilerini de kapsayan bölümleriyle -bence gözden kaçmıș-, Meșrutiyet yılIarının "Cinsel Bilgiler Ansiklopedisidir"! Bu bölümlerden fazla alıntı yapmayacağım!.. Dileğim, bu bölümleri, kitabın yeni basımında, okurlarım olarak rahatça okuyabilmeniz. Bu bölümlerde verilen "cinsel" bilgilerin öncelikle erkeklere yönelik olduğunu söylememe gerek yok!... Ancak ilginç bir biçimde kadınların, genç kızların "șehvetî intiyaçlarına" yönelik açıklamalar da az değil...Dönemi göz önünde tutarak, çoğu kez "tıbbî", "fennî" nitemleriyle tanımlanan bu bilgilerin döneme göre doğruluk derecelerini ölçmekten uzağım!... ${ }^{19}$ Balkan Savașı'nın yaratıtı̆ı bunalım ortamında, cinsel hastalıkların çokluğunu düșündüğümüzde, Karagöz Evleniyor'un didaktik içeriği bence daha farklı bir
19 Hayât-ı Tenâsüliyye Hakkında - Musâhabât-ı Mahrem-âne / Sin-i rüșde vâsıl olmuș olanlar için./ Sûret-i mahsûsada i'mâl ve inzâr etdirilmiș bir hayli resimler ile müzeyyen /, Câmi' ve mürettibi : B.M.Ș., Nâșiri : Bâb-ı âlî Caddesinde 72 numarada Ahâli İçin Âsâr-ı Müfîde Kütübhânesi, Dersaadet, 1329. 
anlam kazanıyor... Karagöz Evleniyor'daki "teknik” bilgilerin ilk kez açık açık yazıldığını görürüz... Ancak buradaki bilgilerin, nicedir Türkçede bilinen Kabusnâme, Bah-nâme, Zenân-nâme vb. yapıtlara benzemediğini, hele Kamasutra çevirilerinden hiç alınmadığını yapacağımız küçük bir incelemeyle kolayca söyleyebiliriz. İster istemez 1912 yılının bu cesur yazarını, bu bilgileri yazarken yararlandığı, aktardığı kaynak kitapları da merak ediyoruz !...

Ciddî - [s.44] : Gevezelik ve eğlenceden sonra muhtasaren izdivâca âid sıhhat kâidelerini zikr etmek arzû ediyoruz ki evlenmek arzusunda bulunan kimseler bu kâidelerden fevkalâde müstefîd olurlar.

Evvelâ Tenâsül Uzuvları - [s.44] : Bu uzûvları gayet iyi kullanarak ve yormayarak dâimâ kuvvetli bir hâlde

bulundurmak iktizâ eder. Kesret-i cimâ' dahi bir takım marazlar tevlîd eder......

Cimâ'nın Adedi - [s.45] : Erkek yirmi yașından otuz yașına kadar haftada ikiden dörde kadar icrâ olunabilir. Her gün cimâ' yahûd günde dört beș cimâ' kat'iyyen muzırdır.

Cimâ'nın Vaziyeti - [s.45] : Ayakta ve oturarak cimâ' icrâ etmek kadar muzır bir hâl tasavvur olunamaz

İzdivâca Aid Sâir Vesâyâ-yı Sıhhıye - [ss.46-58] : Erkek giriștiği hayat mübârezesinde zayıflayan kollarını, vücûdunu ancak yalnız kendine âid kadının, zevcesinin agûșunda dinlendirebilmektedir...öyle sefîh ve kayıdsız, tâbıtasız...kadınsız geçecek bir hayat yașanılmamıștır....Sevimli bir zevce ve tombul, șen sıhhati yerinde çocuklarla tamamlanmıș bir âilenin saâdetini tanımamak...hayatta en büyük zavallılık ișe budur........Evet bir zevc zevcesinde șehvetî intiyâcını teskîn için öyle aklına gelen sûrette hareket eder, bir delilik, bir rehberin güzel nasihatlerini, fennî șekillerini, hıfz-ı sıhhate muvâfık sûretlerini icrâ etmez ise neticede mağlûb ve yorgun düșer...Haya tını yașayamamıș olur, hastalanır, zayıflanır, çırpınır, ölür 
Son Bahis - [ss.58-63] :

Karagöz, "talâk-ı selâse" ile boșadığı karısıyla kavga nedenlerini Hacivat'a anlatmaya bașlar. Zil çalmayı öğrenmek isteyen karısını, ders veren öğretmenle basınca, ikisini de öldüresiye dövüp evden attığını ve boșadığını söyler. Hacivat da arada çocuk olduğunu, eğer pișmanlık duyup karısıyla tekrar evlenemeyeceğini söyleyince, bu kez çekișme, atıșma aralarında bașlar. Hacivat, Karagöz'e, üç kez boș ol dediği için yeniden evlenmede "hulle" gerektiğini, bir "hîle-i șer'iyye" olarak "hulle"yi de bildiğini belirtir :

Hacivad : Çaresi birini bulup karıyı muvakkaten ona vermeli.

Karagöz : Kimi bulmalı acaba?..

Hacivad : Ma'hûd zil muallimi...

Karagöz : Bırak șu çingeneyi.

Hacivad : Bașka kim var...

Karagöz : Bilmem...

Hacivad : Ah Karagözüm ah...

[Karagöz ağlamaya bașlar]

Hacivad : Ağlama Karagöz, ağlama..Ben her șeyin kolayını bulurum.Bak iște buna da çâre buldum.Seni ne kadar sevdiğimi anla...

Karagöz : Ne buldun..

Hacivad : Yaklaș da söyleyelim...

Karagöz : Söyle bakalım...

Hacivad : Daha yaklaș daha...

Karagöz : Hadi yaklaștım...

Hacivad : Karıyı ben alayım...

Karagöz : Bu nasıl lâf?...

Hacivad : Nasıl lâf olacak, dosdoğru bir lâf.

Karagöz : Ah... Ah...Al Hacivâd al... ne yapalım, bașa gelen çekilir... Zavallı yavrucağı da karı değil ya canımı da istesen vereceğim geliyor!... 
EFDAL SEVINÇLi

\section{Sonuç}

20 Bin Bir Bûse: En Șen, En Șuh Hikâyeler / 1923-24 Istanbul'undan Erotik Bir Dergi, Hazırlayan: Ömer Türkoğlu; Sunuș Irvin Cemil Schick, Istanbul Kitap Yayınevi, 2005.
Karagöz Gazetesi'nin “Karagöz Kütübhânesi” olarak yayımladıkları Karagöz Evleniyor'un arkasının gelmediğini biliyoruz. Gerçek yazarını öğrenemediğimiz, içeriğiyle çağının çok ilerisinde olduğunu gördüğümüz, dönemin gençlerinin cinsel eğitimine katkıda bulunmayı amaçlayan Karagöz Evleniyor, oyun içerikli bölümleri ile "kuramsal" bilgilerin örtüștüğü ilginç bir yayın olurken "Karagöz'ün Çapkınlıklarını, Açık Hikâyeler" olarak anlatan yayınlar izleyecek ve bu günlerde, Eylül romanının yazarı Mehmet Rauf'un adı, așk öykülerinden erotik öykülere uzanan içeriğiyle yayınlanan Binbir Buse ${ }^{20}$ (1923-24) dergisiyle birlikte "erotik yazar" olarak anılacaktır!.

Türkiye Basmaları Toplu Kataloğu Arap Harfli Türkçe Eserler [1729-1928]'in daha VI. Cildi [I-I-J] yayımlanabildiği bugünlerde, Karagözümüzün oyunlarını içeren yazmalardan basılı oyun kitaplarına, canlandırdığı tipler üstüne, hâlâ ayrıntııı bir araștırmanın yapılmadığını biliyoruz. Yine gazetelerde kalan Karagöz oyunlarından, incelemelere, nice ürün, hâlâ bizleri bekliyor.

\section{KAYNAKÇA}

And, Metin. Dünyada ve Bizde Gölge Oyunu. Ankara: T. Iș Ban. Yay.,1977. And, Metin. Geleneksel Türk Tiyatrosu, Köylü ve Halk Tiyatrosu Gelenekleri. İstanbul: Inkılâp Kit. Yay., 1985.

Bardakçı, Murat. Osmanlıda Seks: Sarayda Gece Dersleri. İstanbul: Gür Yay.,1992.

Bayram A. ve Çöğenli, M.S. yayına haz.Seyfettin Özege, Bağıș Kitapları Katalogu, c.1-2, A-K, Haz.: A.Bayram - M.S.Çöğenli. Erzurum: Atatürk Üniversitesi Basımevi, Atatürk Üniversitesi Kütüphanesi Yayınları, 1978.

Cahid, Burhan. Karagözün Fıkraları. İstanbul: Hacivad Matbaası,1926.

Çeviker, Turgut. Gelișim Sürecinde Türk Karikatüri-I- Tanzimat ve istibdat Dönemi (1867-1878/1878-1908) ; C.-II- Meșrutiyet Dönemi (19081918) ; c.-III- Kurtuluș Savașı Dönemi (1918-1923), İstanbul: Adam Yayınları, 1986, 1988, 1991. 


\section{CINSEL BILGILERI ÖĞRENIRKEN SAĞDICIMIZ KARAGÖZ}

Çeviker, Turgut. "Karikatür ve Karagöz”, Karikatür Üzerine Yazılar. İstanbul: Iris Yay., 1997, ss.1 -5.

Çeviker, Turgut. “ilk Türk Karikatürcüsü Ali Fuat Bey”, Karikatür Üzerine Yazılar. Istanbul: Iris Yay., 1997, ss.11 - 15.

Çeviker, Turgut. Osmanlı Tokadı. İstanbul: Adam Yay., 1986, ss. 9 - 11.

Duru, Orhan. "Muhalif Oyun Karagöz", Sanat Dünyamız, Sayı : 74, Kıș 1999, ss.153-157.

Erdoğan, Sema Nilgün. La Vie Sexuelle des Ottomans. İstanbul, Dönence Basım ve Yayın, 1998.

Ertop, Konur. Türk Edebiyatında Seks. İstanbul: Seçme Kitaplar Yay., 1977.

Georgeon,François. “Osmanlı Imparatorluğu'nda Gülmek mi?”, Doğuda Mizah, Hazırlayanlar: I. Fenoglio - F.Georgeon, Çev.: Ali Berktay. İstanbul: YKY, 2000, ss.79-101.

Hayât-ı Tenâsüliyye Hakkında - Musâhabât-ı Mahrem-âne / Sin-i rüșde vâsıl olmuș olanlar için./ Sûret-i mahsûsada i'mâl ve ihzâr etdirilmiș bir hayli resimler ile müzeyyen /, Câmi' ve mürettibi : B.M.Ș., Nâșiri : Bâb-ı âlî Caddesinde 72 numarada Ahâli için Âsâr-ı Müfîde Kütübhânesi, Dersaadet, 1329.

Heinzelmann, Tobias. Osmanlı Karikatüründe Balkan Sorunu (19081914), Çev.:T. Noyan. İstanbul: Kitap Yayınevi, 2004.

Kılıç, Çiğdem. "Ortaoyunu ve Karagöz Metinlerinde Kullanılan Ilençler, Sitem Sözleri, Așağılamalar”, Actaturcica, Yıl 1, Sayı:2/1, Temmuz, 2009, www.actaturcica.com.

Kolektif, "Burhan Cahit Morkaya (1892-1949)", Tanzimattan Bugüne Edebiyatçılar Ansiklopedisi, c. II, İstanbul: Yapı Kredi Yay., 2001, s.570.

Koz, M.Sabri. "Karagöz Üzerine Seçme Kaynakça”, Yıktın Perdeyi Eyledin Vîrân. İstanbul, YKY, 2004, ss.201-214.

Kudret, Cevdet. Karagöz-I-III. Ankara: Bilgi Yay.,1968,1970.

Poyraz, T. ve Tuğrul, N. Tiyatro Bibliyografyası (1859-1928). Haz. : T. Poyraz- N. Tuğrul, Ankara: Milli Kütüphane Yayınları, 1967.

Rahîm, Ihsan. Șarkıı Kantolu Karagöz Kitabı, Asya Kütüphanesi, Hürriyet Matbaası, l.cilt /10 Hikâye, 1325-1909.

Sakaoğlu, Prof. Dr.Saim. Türk Gölge Oyunu Karagöz. Ankara,: Akçağ Yay., 2003.

Sevinçli, Efdal. Namık Kemal ve Tiyatro.Izmir: D.E.Ü. G.S.F. Yay. , 1992.

Sevinçli, Efdal. yayına haz. Karagöz Evleniyor, Karagöz Kütübhânesi, Aded : 2, Nâșiri : Karagöz Gazetesi, Her Hakkı Mahfûzdur, Der-saadet / istanbul: Matbaa-i Nefâset - Vezir Hân, 1329. [Karagöz Evleniyor, izmir: Egetan Bas.Yay., 2010]

Sevinçli, Efdal. yayına haz. Karagöz Matbahda, Karagöz Kütübhânesi Aded : 1, Nâșiri : Karagöz Gazetesi, Her Hakkı Mahfuzdur, istanbul: Matbaa-i Nefâset - Vezir Hân, 1329 [Karagöz Mutfakta, basıma hazırlanıyor]

Siyavușgil, Sabri Esat. Karagöz, Psiko-sosyal Bir Deneme, Maarif Vekaleti, 1941.

Türkoğlu; Ömer. haz. Bin Bir Bûse: En Șen, En Șuh Hikâyeler / 192324 İstanbul'undan Erotik Bir Dergi. Sunuș Irvin Cemil Schick. İstanbul: Kitap Yayınevi, 2005. 
Üyepazarcl, Erol. “Uzun Soluklu Bir Halk Gazetesi Karagöz ve Kurucusu Ali Fuad Bey”, Müteferrika, Sayı : 19, 2001.

Üyepazarcı, Erol. "Uzun Soluklu Halka Dönük Bir Mizah Gazetesi : Karagöz", Birgün Gazetesi, 23 Nisan 2008.

Ze'evi, Dror. Müs/üman Osmanlı Toplumunda Arzu ve Așk / 1500-1900. Çev.:Fethi Aytuna, İstanbul: Kitap Yayınevi, Ekim 2008.

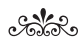

